\title{
Isolation, Screening and Characterization of Cellolytic Bacteria from Agricultural Fields of Narmada District
}

\author{
Alpesh Bhimani ${ }^{*}$ and Nikunj Sohaliya ${ }^{2}$ \\ ${ }^{*}$ Department of Agricultural Microbiology, Navsari Agricultural University, Navsari. ${ }^{2}$ Department of Plant Pathology, Navsari \\ Agricultural University, Navsari
}

\begin{abstract}
The aim of this presented work is to elucidate the screening and characterization of cellulolytic bacteria from soil. Soil samples from different areas of agricultural fields of Narmada district were used for the screening of cellulolytic bacteria by serial dilution and pore plate method. Isolates were additionally characterized by morphological and biochemical tests. Out of forty nine isolates were selected on the basis of clear zone produced $7 \mathrm{~mm} \geq$. These five potential isolates were further screened for cellulolytic activity among which three isolates AII3, AI3 and CIII5 exhibited promising activity of cellulase in agar plate assay. Isolation, screening and characterization of isolates for cellulolytic activity provided appreciated and novel enzymes for the alteration of cellulolytic waste into valuable compost.
\end{abstract}

Key words: Cellulolysis, Bacteria, Agricultural Waste, Characterization.

\section{INTRODUCTION}

Cellulose is a homopolysaccharide of glucose residues linked with $\beta$-1, 4-glycosidic linkage. Copious accessibility of cellulose makes it striking substrate for producing many industrially important metabolites. Desolately, most of the cellulosic biomass is often disposed of by burning. This is not limited to developing countries alone, but is measured a comprehensive phenomenon. With the help of cellulolytic enzyme system, cellulose can be altered to glucose which is a multi-valued product, in a considerably economical and biologically favourable process. Cellulose degradation is mainly the bio-process performed by the cellulases enzymes. Cellulase enzyme system includes three classes of soluble extracellular enzymes: 1, 4- $\beta$-exoglucanase, 1, 4$\beta$-endoglucanase and $\beta$-glucosidase.

Exoglucanase is essential for breaking of the non-reducing end of a cellulose chain and breaking of the elementary fibrils from the crystal-like cellulose. Endoglucanase is accountable for randomly breaking of $\beta-1-4$, glycosidic bonds in a cellulose chain. $\beta-1,4-$ glucosidase hydrolyses water-soluble cellodextrin and cellobiose to glucose (1-2). Only the interaction of this three enzymes makes the complete hydrolysis of cellulose to glucose (3-5) or mineralized to $\mathrm{H}_{2} \mathrm{O}$ and $\mathrm{CO}_{2}$. Microbial system is best suitable source for cellulase system extraction found in the gut of organisms living in cellulosic substrates as their major food. Insects like bookworm (Lepidoptera) and termites (Isopteran) are found to have important symbiotic microflora in their digestive track responsible for Cellulolysis (6-7).

Cellulosic activities have been reported in many microorganisms including many fungal and bacterial strains both anaerobic and aerobic. Chaetomium, Fusarium, Myrothecium, Trichoderma. Aspergillus, Penicillium and so forth, are some of the accounted fungal species accountable for cellulolysis. Cellulose degrading bacterial species include Clostridium, Trichonympha, Bacteroides, Actinomycetes, Ruminococcus albus, succinogenes, Methanobrevibacter ruminantium and Butyrivibrio fibrisolvens, $(8,9)$.

*Address of Correspondence: Bhimani Alpesh, Dept. of Agricultural Microbiology, Navsari Agricultural University, Navsari - 396421, Gujrat, India. E-mail- bhimani4@gmail.com 
Cellulase has been used in several industrial processes such as biofuels alike bioethanol (10, 11), triphasic biomethanation (12); plant waste and agricultural management $(13,14)$; ligand binding and chiral separation studies (15) due to its massive applicability.

This work focusses on the isolation of cellulolytic bacteria from soil of different organic farms of agricultural universities and explore their cellulose degrading ability.

\section{MATERIALS AND METHODS}

\section{Sample collection}

The soil samples (10gm) were collected from agricultural fields of Narmada District were screened for the isolation of cellulose degrading bacteria. With the help of sterile spatula soil samples were collected from surface and 4, 8 and $12 \mathrm{~cm}$ depth. Sterile polythene plastic bags were used for sampling. The samples were then brought to the laboratory for microbiological analysis. To minimize saprophytic developments isolation of all the samples were done within 3-4 $\mathrm{h}$ of collection.

\section{Isolation of Bacteria from Soil}

Cellulolytic bacteria were isolated from soil by using culture enrichment and pore plate methods. The Modified Han's (MH) medium along with Carboxymethylcellulose as sole carbon source was used for this purpose (16). The medium used for cellulolytic bacteria contains CMC $1.88 \mathrm{~g}$, sodium citrate $0.5 \mathrm{~g}$, KH2PO4 2.0 g, K2HPO4 7.0 g, MgSO4.7H2O 0.1 g, (NH4)2SO4 1.0 g, Agar $10 \mathrm{~g}$, Congo red $0.20 \mathrm{~g}$, PH 7.0, Distilled water 1 lit. The plates were incubated for $2-3$ days at $37^{\circ} \mathrm{C}$ and observed for clear zone around the colony. To visualize the hydrolysis zone the plates were flooded with an aqueous solution of $1 \%$ Congo red for $15 \mathrm{~min}$ (9).To visualize clear zone formed by cellulase positive strains the plates were distained using $1 \mathrm{M} \mathrm{NaCl}$ solution. For identification and cellulase production the bacterial colonies having clear zone were selected. Further bacterial strains were purified by repeated streaking. The purified colonies were preserved at $4^{\circ} \mathrm{C}$.

\section{Primary screening of isolates by agar plate assay}

Cellulose degradation activity was analysed as a diameter of clear zone in the Carboxymethylcellulose congored plate. Following formula was used to calculate cellulolytic index. (11)

$$
\begin{aligned}
& \text { Cellulolytic index }= \text { (Diameter of zone } \text { Diameter of Bacterial colony) } \\
& \text { Diameter of Bacterial colony }
\end{aligned}
$$

\section{Morphological characterization of isolates}

Bacterial isolates were characterized by their morphological and physiological features. Macro-morphological characteristics were study by observing colony morphology, gram's staining of isolates was performed and slides were examined under binocular optical microscope to observe the cellular morphology.

\section{RESULTS AND DISCUSSIONS}

\section{Sample Collection and Isolation}

Cellulose is the major fraction of organic carbon in soil and main structural component of plants. Soil microbes, are responsible for recycling of this organic carbon to the environment (14). Cellulosic material degradation is a complex process and requires involvement of microbial cellulolytic enzymes. Habitations where cellulosic substrates present are the preeminent sources for isolation of cellulose degrading bacteria (15). Several bacterial species have been discovered which have capacity to alter cellulose to simple sugars (16) but requirement for anew isolated cellulolytic microorganisms still continues (17). With the aim of isolation of cellulolytic bacteria from soil, total seven soil samples (A1I, A1II, A1III) and (A1I, A1II, C1I, D1I) were collected. Cellulose degrading bacteria were enriched and isolated by basal salt media (BSM), which contained, NaNO3 2.5 g; KH2PO4 2 g; MgSO4 0.2 g; $\mathrm{NaCl} 0.2$ g; $\mathrm{CaCl} 2.6 \mathrm{H} 200.1 \mathrm{~g}$ supplemented with cellulosic substrate CMC Na salt as a sole carbon source and nutrient agar. After dilution plate technique, well isolated colonies showing distinct colony morphology were selected and further purified by sector streaking. Altogether, 49 isolates were obtained in pure culture and were preserved at $4{ }^{\circ} \mathrm{C}$ temperature for further studies. 


\section{Morphological and biochemical characteristics of cellulolytic bacterial isolates}

Five cellulolytic bacteria were isolated from soil. All bacterial isolates are Gram positive, rod shaped, motile and endospore forming bacteria.
They all gives positive reactions for Oxidase, Catalase, Gelatinase, Vogues Proskauer, Amylase, citrate utilization test and Negative reactions for methyl red and Indole test,. All isolates ferment glucose, fructose \& sucrose but not mannitol \& lactose.

Table 1: Morphological and cultural Characteristics of bacterial isolates

\begin{tabular}{|c|c|c|c|c|c|c|c|c|}
\hline \multirow{2}{*}{$\begin{array}{c}\text { Sr. } \\
\text { no }\end{array}$} & \multirow{2}{*}{ Isolates } & \multicolumn{2}{|c|}{ Morphological Characteristics } & \multicolumn{4}{|c|}{ Cultural Characteristics } \\
\cline { 3 - 9 } & $\begin{array}{c}\text { Grams } \\
\text { staining }\end{array}$ & Shape & $\begin{array}{c}\text { Arrange } \\
\text { ment }\end{array}$ & Colony size & $\begin{array}{c}\text { Shape/ } \\
\text { Form }\end{array}$ & $\begin{array}{c}\text { Margin/Ed } \\
\text { ge }\end{array}$ & Elevation \\
\hline 1 & BI2 & $\mathrm{G}(+)$ & Rod & Chain & Intermediate & Round & Erose & Umbonate \\
\hline 2 & AII3 & $\mathrm{G}(+)$ & Rod & Chain & Intermediate & Round & Erose & Umbonate \\
\hline 3 & AI3 & $\mathrm{G}(+)$ & Rod & Chain & Intermediate & Irregular & Undulate & Raised \\
\hline 4 & CIII5 & $\mathrm{G}(+)$ & Rod & Single & Intermediate & Round & Entire & Umbonate \\
\hline 5 & DI1 & $\mathrm{G}(+)$ & Rod & Single & Intermediate & Round & Undulate & Pulvinate \\
\hline
\end{tabular}

\section{Screening of isolates by agar plate assay}

Cellulolytic activity of bacterial isolates was based on clear zone of degraded CMC area around the colony. Cellulolytic activity test showed that isolate AII3, AI3 and CIII5 has the largest cellulolytic index $(4.0,2.0 \& 2.0)$ isolate BI2 \& isolate DI1 has the smallest cellulolytic index (0.9 \& 0.4) respectively. Based on cellulolytic index and growth isolate AII3, AI3 and CIII5 were potential isolates.

Table 2: Cellulolytic activity of bacterial isolates

\begin{tabular}{|c|c|}
\hline Isolates No. & CMCase Zone Ratio (cm) \\
\hline BI2 & 0.9 \\
\hline AII3 & 2 \\
\hline AI3 & 4 \\
\hline CIII5 & 2 \\
\hline DI1 & 0.4 \\
\hline
\end{tabular}

\section{CONCLUSION}

According to this study, our isolation, screening, morphological and cultural identification methods were quick and efficient for allowing us to identify several good cellulase producing bacteria from a wide variety of samples. Isolation of naturally occurring cellulase producing bacteria from the environment is important for degradation of agricultural waste. All of our positive isolates may be an integral part of future work. It develops good cellulases or produce efficient cellulase producing systems such as microbial consortia which can be used for industry. Isolation and characterization may provide a good starting point for the discovery of such beneficial enzymes.

\section{CONFLICT OF INTEREST}

There is no conflict of interest in this present research paper. This research work is not a part of any other studies and it is our original work.

\section{REFERENCES}

1. Shewale JG. "Glucosidase: its role in cellulase synthesis and hydrolysis of cellulose". International Journal of Biochemistry. 1982; 14: 435-443.

2. Woodward J and Wiseman A. "Fungal and other $\beta$-glucosidases: their properties and applications." Enzyme and Microbial Technology. 1983; 4: 73-79.

3. Ryu and Mandels M. "Cellulases: biosynthesis and applications." Enzyme and Microbial Technology. 1980; 2: 91-102.

4. Samdhu and Bawa. "Improvement of cellulase activity in Trichoderma." Applied Biochemistry and Biotechnology. 1992; 34: 175-192.

5. Wood TM. "Synergism between enzyme components of Penicillium pinophilum cellulase in solubilizing hydrogen ordered cellulose." Journal of Biochemistry. 1989; 260: 37-43.

6. Dillon RJ and Dillon VM. "The gut bacteria of insects non-pathogenic interaction." Annual Review of Entomology. 2004; 49: 71-92.

7. Saxena, Bahadur, Varma. "Cellulose and hemicelluloses degrading bacteria from termite gut 
and mould soils of India." The Indian Journal of Microbiology. 1993; 33: 55-60.

8. Milala, Shugaba, Gidado, Ene, Wafar. "Studies on the use of agricultural wastes for cellulase enzyme production by A. niger." Journal of Agriculture and Biological Science. 2005; 1: 325-328. 9. Schwarz WH. "The cellulosome and cellulose degradation by anaerobic bacteria." Applied Microbiology and Biotechnology. 2001; 56: 634-649. 10. Ekperigin MM. "Preliminary studies of cellulase production by Acinetobacter anitratus and Branhamella sp." African Journal of Biotechnology. 2007; 1: 28-33.

11. Vaithanomsat, Chuichulcherm, Apiwatanapiwat. "Bioethanol production from enzymatically saccharified sunflower stalks using steam explosion as pretreatment." Proceedings of World Academy of Science, Engineering and Technology. 2009; 37:140-143.

12. Chakraborty N, Sarkar GM, and Lahiri HC. "Cellulose degrading capabilities of cellulolytic bacteria isolated from the intestinal fluids of the silver cricket." Environmentalist. 2000; 20: 9-11.
13. Lu JW, Wang HT, Nie YF. "Effect of inoculating flower stalks and vegetable waste with ligno-cellulolytic microorganisms on the composting process." Journal of Environmental Science and Health. 2004; 39: 871- 887.

14. Mswaka and Magan. "Wood degradation, and cellulase and ligninase production, by Trametes and other wood-inhabiting basidiomycetes from indigenous forests of Zimbabwe." Mycological Research. 1998; 102: 1399- 1404.

15. Nutt A, Sild V, Prtterson V, Johansson V. "Progress curve as a means for functional classification of cellulases." Europian Journal of Biochemistry. 1998; 258: 200.

16. Kasana RC, Salwan R, Dhar H, Dutt S, Gulati A. A rapid and easy method for the detection of microbialcellulases on agar plates using gram's iodine. Current Microbiology. 2008; 5: 503-507.

17. Brander JR, Gillings MK, Nevalainen, $\mathrm{MH}$. Qualitative assessment of hydrolytic activities in Antarctic micro fungi grown at different temperatures on solid media. World J microbial. Biotechnol. 1999; 15: 131-132. 